\title{
Editorial
}

\section{John Quay}

Welcome to volume 20, issue 1, of the Journal of Outdoor and Environmental Education. In this issue, we celebrate specific contributions to the 19th National Outdoor Education Conference, the Australian version, which took place at the University of the Sunshine Coast in Queensland from 29 March to 1 April 2016. In drawing this issue together, the support of Glyn Thomas was vital. The tasks of assessing, reviewing, and developing the papers in this issue were significantly supported by Glyn, who played a major role in convening the conference.

The first paper, "Innovation and Outdoor Education," captures the keynote presentation of Simon Beames. A keynote paper challenges conference delegates, and Beames' paper does a masterful job of this by raising questions concerning technology and educational practices, while at the same time interpreting the conference theme "innovate-educate-celebrate." It is clear that this challenge was taken up across the conference, particularly in the papers chosen to appear in this issue.

Beames applies the double-edged sword analogy to the use of various technologies in outdoor education. This topic is contextualised in the work of Glyn Thomas and Brendon Munge, whose paper "Innovative Outdoor Fieldwork Pedagogies in the Higher Education Sector: Optimising the Use of Technology" suggests a framework via which teachers may assess the use of various technologies in outdoor education fieldwork. The goal is transformation of student learning opportunities, rather than mere replacement or augmentation of existing pedagogies.

The paper by David Spillman, "Coming Home to Place: Aboriginal Lore and Place-Responsive Pedagogy for Transformative Learning in Australian Outdoor Education," continues the emphasis on transformation. Here Spillman highlights how a pedagogical focus on place may to some extent redress the "placelessness" felt by many in contemporary Australian society. Such a focus is exemplified, Spillman suggests, in the establishment of local partnerships between outdoor educators and Aboriginal people, partnerships which draw on Aboriginal Lore as a way to undermine the colonial and anthropocentric discourses which continue to influence outdoor education practices.

Another challenging paper is authored by Tonia Gray, Sandy Allen-Craig, and Cathryn Carpenter. "Selective Hearing: The Unrecognised Contribution of Women to the Outdoor Profession" draws attention to an issue which affects many working in outdoor education and cognate professions. As debates about the status of women in professional life highlight the many unacceptable inconsistencies that continue to prevail, it is time that we looked in the mirror at how we are travelling. The analysis shared in this paper certainly provides such a look, raising questions about how we should proceed that require answers in the form of actions.

As Beames points out, innovation is not just about technology but deeply involves pedagogy. In their paper "Those Who Teach Learn: Near-Peer Teaching as Outdoor Environmental Education Curriculum and Pedagogy," Lucas Bester, Gregg Muller, Brendon Munge, Marcus Morse, and Noel Meyers share a pedagogical innovation applied in their programme. Near-peer teaching draws on students who have already successfully progressed through various aspects of a programme to support the teaching of those who are new to these aspects. Through a qualitative investigation, they examine and report on this innovation.

The next paper in this issue is authored by Jessie Booth and James Neill. Titled "Coping Strategies and the Development of Psychological Resilience in Outdoor Education," this paper explores various subtle aspects of the experiences of participants, illuminating those concerned with resilience. The efficacy of particular coping strategies is emphasised, highlighting the importance of such strategies in the conduct of outdoor education programmes.

A seemingly perennial issue confronting those teaching in university courses aimed at preparing graduates is whether those graduates are ready to undertake the challenges they will be confronted with. In their paper "What are the Capabilities of Graduates Who Study Outdoor Education in Australian Universities? The Case for a Threshold Concepts Framework," Scott Polley and Glyn Thomas explore this issue and propose that a threshold concepts framework may provide a way forward. Such a framework supports a process through which to discuss, and potentially reach agreement on, the forms of knowledge, skills, and experiences that graduates of university outdoor education programmes require.

The final contribution to this issue is a book review penned by Glyn Thomas of Adventure Programming and Travel for the 21st Century edited by Rosemary Black and Kelly Bricker.

I commend this issue to you as an opportunity to celebrate some of the very innovative work going on in Australia and beyond in outdoor and environmental education. And I sincerely thank all involved in its production: a real community effort.

John Quay, Ph.D Editor 